\title{
Quantitation of cyclic nucleotides in mammalian cells and in human urine by high-performance liquid chromatography/mass spectrometry
}

\author{
Heike Burhenne ${ }^{1 *}$, Kim Tappe ${ }^{1}$, Kerstin Beste ${ }^{1}$, Ulrike Voigt ${ }^{1}$, Corinna Spangler ${ }^{1}$, Dimitrios Tsikas $^{2}$, Volkhard Kaever ${ }^{1}$, \\ Roland Seifert ${ }^{1}$
}

From 5th International Conference on cGMP: Generators, Effectors and Therapeutic Implications Halle, Germany. 24-26 June 2011

\section{Background}

The cyclic nucleotides adenosine 3',5'-cyclic monophosphate (cAMP) and guanosine $3^{\prime}, 5^{\prime}$-cyclic monophosphate (cGMP) are well-known second messengers. They play an important role in signal transduction. They control numerous functions ranging from ion channel opening to regulation of gene expression.

In 1963, cAMP and cGMP were detected in rat urine. Indeed, this was the first proof of cGMP in biolocigal systems [1]. In 1984, Newton et al. demonstrated the possible presence of cytidine 3',5'-cyclic monophosphate (cCMP) in various rat tissues [2] and, two years later, of uridine 3',5'-cyclic monophosphate (cUMP) [3] by fast atom bombardment. Furthermore, cCMP was supposedly detected in urine of patients with acute leukemia $[4,5]$ by radioimmuno assay. These findings point to a biological function of cCMP and cUMP. However, due to significant methodological problems, studies of the biological function of cCMP und cUMP were no longer continued.

Recently, we have developed a method based on highperformance liquid chromatography-coupled mass spectrometry (HPLC-MS/MS), which allows the simultaneous determination of all cyclic nucleotides (cNMPs). Using this highly sensitive method we were able to detect and quantify cAMP, cGMP and cCMP as well as cUMP in various mammalian cell lines. We have optimized this method for the quantitation of cyclic nucleotides in complex biolocigal matrices, like urine and organs.

\footnotetext{
* Correspondence: burhenne.heike@mh-hannover.de

${ }^{1}$ Institute of Pharmacology, Hannover Medical School, Germany
}

Full list of author information is available at the end of the article

\section{Methods}

Nucleotide extraction of cells was performed by treating cells with a mixture of organic solvents and heating the samples at $98^{\circ} \mathrm{C}$. After centrifugation the supernatant fluid was evaporated under a nitrogen stream and the residual pellet was resuspended in water. Detection and quantitation of cNMPs was achieved by an analytical method based on HPLC-MS/MS.

To avoid serious matrix effects due to the complex urine composition we enzymatically synthesized ${ }^{13} \mathrm{C}^{15} \mathrm{~N}$ labeled internal standards for each cyclic nucleotide. Urine sample preparation was achieved by treating urine with acetonitrile containing those standards. The readout was performed as described above. The cCMP concentration was normalized to mmol creatinine. Creatinine concentration in urine was determined by gas chromatography -MS.

\section{Results and discussion}

We could show that, in addition to cAMP and cGMP, cCMP and cUMP are present in all studied cell lines (Table 1). Remarkably, the cCMP- and cUMP-contents in HeLa cells are comparable to the cGMP contents, and in B103 cells the the cCMP- and cUMP-content is even two-fold and three-fold higher, respectively.

Moreover, we analyzed human urine from healthy volunteers for cyclic nucleotides by HPLC-MS/MS. Our studies revealed that besides cAMP and cGMP, cCMP is present in human urine.

\section{Conclusion}

Our data suggest that cCMP and cUMP play different roles in the regulation of the function of cell types origi- 
Table 1

\begin{tabular}{|c|c|c|c|c|c|}
\hline \multicolumn{6}{|c|}{ cNMP content $\left(\mathrm{pmol} / 10^{6} \mathrm{cells}\right)$} \\
\hline Cell type & Lineage & CAMP & cGMP & CCMP & cUMP \\
\hline HeLA & epithelial cells & $2.1 \pm 0.5$ & $1.5 \pm 0.5$ & $0.3 \pm 0.1$ & $0.7 \pm 0.3$ \\
\hline $\mathrm{HL}-60$ & myeloid cells & $7.0 \pm 1.4$ & $0.3 \pm 0.1$ & $0.1 \pm 0.03$ & $0.3 \pm 0.03$ \\
\hline$J 774$ & macrophages & $11.0 \pm 1.6$ & $1.2 \pm 0.1$ & $0.5 \pm 0.02$ & $1.2 \pm 0.1$ \\
\hline $\mathrm{CHO}$ & epithelial cells & $33.3 \pm 4.0$ & $10.2 \pm 1.3$ & $8.0 \pm 1.6$ & $6.7 \pm 1.8$ \\
\hline B103 & neuroblastoma cells & $55.1 \pm 7.3$ & $7.5 \pm 0.8$ & $14.4 \pm 1.5$ & $22.3 \pm 2.8$ \\
\hline $\cos -7$ & fibroblasts & $82.2 \pm 11.3$ & $52.1 \pm 3.1$ & $16.3 \pm 1.7$ & $25.1 \pm 2.2$ \\
\hline HEK 293 & epithelial cells & $106.5 \pm 11.3$ & $73.3 \pm 5.2$ & $32.6 \pm 6.2$ & $54.9 \pm 11.3$ \\
\hline
\end{tabular}

nating from various cell lineages and species. The unequivocal identification of cCMP in human urine opens the door for (patho)physiological studies.

\section{Author details}

${ }^{1}$ Institute of Pharmacology, Hannover Medical School, Germany. ${ }^{2}$ Institute of Clinical Pharmacology, Hannover Medical School, Germany.

Published: 1 August 2011

\section{References}

1. Ashman DF, Lipton R, Melicow MM, Price TD: Isolation of adenosine 3', $5^{\prime}$ monophosphate and guanosine 3',5'-monophosphate from rat urine. Biochem Biophys Res Commun 1963, 11:330-334.

2. Newton RP, Salih SG, Salvage BJ, Kingston EE: Extraction, purification and identification of cytidine $3^{\prime} 5^{\prime}$-cyclic monophosphate from rat tissues. Biochem J 1984, 221:665-673.

3. Newton RP, Kingston EE, Hakeem NA, Salih SG, Beynon JH, Moyse CD: Extraction, purification, identification and metabolism of $3^{\prime} 5^{\prime}$-cyclic UMP, 3'5'- cyclic IMP, 3'5'-cyclic dTMP from rat tissues. Biochem J 1986, 236:431-439.

4. Bloch $\mathrm{A}$ : Isolation of cytidine $3^{\prime}, 5^{\prime}$-monophosphate from mammalian tissues and body fluids and its effects on leukemia L-1210 cell growth in culture. Adv Cyclic Nucleotide Res 1974, 5:331-338.

5. Scavennec J, Carcassonne Y, Gastaut JA, Blanc A, Cailla HL: Relationship between the level of cyclic cytidine $3^{\prime}: 5^{\prime}$-monophosphate, cyclic guanosine $3^{\prime}: 5^{\prime}$ - monophosphate, and cyclic adenosine $3^{\prime}: 5^{\prime}-$ monophosphate in urines and leucocytes and the type of human leukemias. Cancer Res 1981, 41:3222-3227.

\section{doi:10.1186/1471-2210-11-S1-P12}

Cite this article as: Burhenne et al.: Quantitation of cyclic nucleotides in mammalian cells and in human urine by high-performance liquid chromatography/mass spectrometry. BMC Pharmacology 2011 11(Suppl 1):P12.

\section{Submit your next manuscript to BioMed Central and take full advantage of:}

- Convenient online submission

- Thorough peer review

- No space constraints or color figure charges

- Immediate publication on acceptance

- Inclusion in PubMed, CAS, Scopus and Google Scholar

- Research which is freely available for redistribution

Submit your manuscript at www.biomedcentral.com/submit
C Biomed Central 